\title{
THE USE OF SKIMMING STRATEGI TO IMPROVE STUDENTS' READING COMPREHENSION : A STUDY AT UNIVERSITY OF TIMOR
}

\author{
Sefrina Maria Seuk Asa*) \\ Noer Jihad Saleh**) \\ H. Sudarmin Harun**) \\ *) Nursing Program at University of Timor, Atambua Campus. Jl. Wehor Kabuna Haliwen, Atambua East Nusa Tenggara. \\ Post: 85711. Email: rseuk@yahoo.com. Phone: 082359551637 \\ **) English Lunguage Study Program, Faculty of Since of Culture, University of Hasanuddin Makasar.
}

\begin{abstract}
ABSTRACK
The objectives of the research were to find out if there was any significant improvement of students' comprehension in reading through skimming technique.the use of this research is pre-experiment design, based one group pre-test and post-test. The subjects of this research were the second semester students at University of Timor. The result of research showed that score mean post-test is higher of the pre-test. The score mean pre-test is 39.38 up to post-test is 73.50 it means that, after treatment the students has the higher score mean post-test. The result t-test of the students pre-test and pos-test is 13.68, than the result standar deviation of pre-test is 16.79 and than post-test of standar deviation is 11.82 . there was a statistically significant improvement of students' reading comprehension. This suggests that the skimming technique can facilitate the students to improve their reading comprehension.
\end{abstract}

Key word: Skimming Strategy, Reading Comprehension

\section{Penggunaan Strategi Skimming untuk Meningkatkan Pemahaman Membaca Siswa}

\author{
Sefrina Maria Seuk Asa*) \\ Noer Jihad Saleh**) \\ H. Sudarmin Harun**) \\ *) Nursing Program at University of Timor, Atambua Campus. Jl. Wehor Kabuna Haliwen, Atambua East Nusa Tenggara. \\ Post: 85711. Email: rseuk@yahoo.com. Phone: 082359551637 \\ **) English Lunguage Study Program, Faculty of Since of Culture, University of Hasanuddin Makasar
}

\begin{abstract}
ABSTRAK
Penelitian ini bertujuan untuk mengetahui sejauh mana strategi skimming meningkatkan pemahaman membaca siswa dan untuk mengeksplorasi penggunaan teknik skimming untuk meningkatkan pemahaman membaca siswa.Metode yang digunakan dalam penelitian ini adalah metode quantitative pre-experimental. Data utama dari penelitian ini di ambil dari hasil pre-test dan post-test. Diantara pre-test dan post-test ini ada treatment untuk melatih siswa melakukan strategi skimming. Hasil penelitian menunjukkan bahwa nilai rata-rata post-test lebih tinggi dari pre-test. Nilai rata-rata pre-test adalah 38,39, hingga post-test adalah 73,50. Ini berarti, setelah pelaksanaan treatment, siswa memiliki nilai rata-rata yang lebih tinggi setelah tes, penelitian menunjukan nilai t-test adalah 13,68 dan t-tabel adalah 2,093 berada pada level signifikansi $\quad 0,000<0.05$ sehingga t-test juga menunjukkan bahwa t-test 13.68 lebih besar dari t-tabel 2.093 di level signifikansi 5\% 13.68> 2.093. Ada peningkatan pemahaman membaca siswa yang signifikan secara statistik. Ini menunjukkan bahwa teknik skimming dapat memfasilitasi siswa untuk meningkatkan pemahaman bacaan mereka.
\end{abstract}

Kata kunci: Strategy Skimming, Kemampuan Membaca 


\section{INTRODUCTION}

Reading is an important skill in teaching and learning English since it is one of four basic language skills that students have to master besides listening, speaking, and writing. Comprehension in reading is the process of extracting and constructing meaning through interaction and involvement with written language (Caldwell, 2008: 4). Consequently, it is necessary that the students should be encouraged to apply a good and effective technique in reading so that they are able to get the information from the text.

Reading covers four concepts; they are alphabetic/decoding, fluency, vocabulary and comprehension. To understand the text in teaching learning, comprehension is one of specific components in teaching reading. Comprehension is the goal of reading. Snow (2002:11) stated that reading comprehension is the process of simultaneously extracting and constructing meaning through interaction and involvement with written language. It means that it uses the words extracting and constructing to emphasize both the importance and the insufficiency of the text as a determinant of reading comprehension. According to Snow (2002:33) stated that comprehension entails three elements: 1) The reader who is doing the comprehending, 2) The text that is to be comprehended; and 3) The activity in which comprehension is a part. Each of these three elements in reading has important to distinguish between what the students brings to reading and what the students takes from reading. It is also affected by some factors, such us the readers' knowledge of language structures, knowledge of text structures and genres, their motivation and their level engagement.

Based on the observasion in University of Timor, the researcher see the teacher/lecture who taught English subject at university of Timor, a crucial problem was found in relation to comprehension of a text. When he/she taught reading comprehension, he/she found that the students did not understand what they read and the student did not get the information from the text. So, students at University of Timor need to be taught the some strategy to improve students' reading comprehension and the students have low level of reading awareness and give negative attitudes and resistance toward reading and also the students need some particular information from the text quickly, such as the name of a person and place, and date of certain event. Hence, students must have the ability to identify particular information and the main idea from the texts.

Alvermann \& Moore (1991) investigate that students are assigned to read increasingly complex materials, but teachers spend little time showing them how to be strategic. Therefore, it is very important to encourage the students to create a different perspectives on why the reading practice is important for themselves. Based on researcher's experience the students tended to gain a low reading comprehension score. It was commonly caused by their difficulties in finding main idea and discovering particular information, especially in a limited time. Therefore it is necessary to guide the students in applying the proper technique to obtain the information from the text appropriately and quickly.

By reading, the students are required to improve their knowledge. Although the reading activity is quite familiar for students, there were still some confusions among them in discovering specific information from the text. Based on researcher's experience at the University of Timor, the students tended to gain a low reading comprehension score. It was commonly caused by their difficulties in finding main idea and discovering particular information, especially in a limited time. The students usually encountered some difficulties in reading comprehension.

Brown (2004:213) explains that skimming is the process of rapid coverage of reading matter to determine its gist or main idea. When the readers skim certain page, they take the main ideas from the reading material without reading all the words. In the act of skimming, the readers focus only on the substantial ideas and skip over the insignificant, marginal, and indegligible parts. Unfortunately, during the teaching learning process, the teachers rarely applied skimming technique, due to lack of information and knowledge about this technique. The application of skimming which was not optimally organized made this condition is leading the students in to the ability of gaining sufficient reading comprehension. 


\section{MATERIAL AND METHOD}

This part contains the methodology of the research. This study employed quantitative based pre-experimental by using one group pre-test and post-test.

\section{Location and Research Design}

This study took place at University of Timor (UNIMOR) Kefamenanu for the students second semester. It was used quantitative based on the pre-experimental by using one group pre-test and post-test. This was to find out whether there is significant diferences between pre-test and post-test through the implementation of skimming technique.

Subject

The populations in this research were the second semester students at University of Timor (UNIMOR) Kefamenanu 2017/2018, which consisted of 100 students. They were divided into two classes (A, B, C, and D) which consisted of 25 students in each class. The samples of this research were the students of classes A.and B. So, the total of population is 100 students. the writer took two classes for sample: the researcher took the samples randomly classes $\mathrm{A}$ and $\mathrm{B}$. The number of class A is 10 students and classes B is 10 students, after randomization process the writer was chosen the 20 students the sample of this randomly as an experimental class. The population is homogenous, because of this condition, the writer choose the randomly sampling technique.

\section{Data Collection}

The data was analyzed from the result of the following activites, those were :

\section{Pre-test and Post-test}

The researcher administred the pre-test which took 45 minutes. The purpose of pretest was to discover the preliminary ability to comprehend reading text. In conducting the pre-test, the researcher provided a multiple choice test in which the items derive from the selection of reading text.

The researcher administered the posttest which also spent 45 minutes. The purpose of this test was to explore the students' improvement in comprehending reading text after the researcher treated using skimming technique. The technique of giving post-test is similar to the pre-test because the researcher wanted to analyze the students improvement after six treatments.

\section{Data Analysis}

The steps in analyzing the data are scoring the students` correct answer in pre-test and post-test using the formula (Depdiknas, 2005 in Rahim, 2016). After that, classifying the students`score into five criteria that is very good, good, fair, poor and very poor. Next, calculating the mean score, standard deviation of students` pre-test and post-test using formula:

1. The formulate of calculation the mean score as fallows:

$$
x=\frac{\sum \mathrm{X}}{\mathrm{N}}
$$

Where :

$$
\begin{aligned}
& \qquad \mathrm{X}= \\
& \text { means score } \\
& \sum \mathrm{X}=\text { the } \\
& \text { total number of the } \\
& \text { students score } \\
& \mathrm{N}=\text { the } \\
& \text { number of the } \\
& \text { students }
\end{aligned}
$$

$$
\text { 2006:320) }
$$

(Gay,

2. Calculation the standard deviation of students by using the following formula:

$$
\begin{aligned}
\mathrm{SS} & =\sqrt{\frac{S S}{N-1}} \\
\sqrt{\frac{\sum X^{2}-\frac{(X)^{2}}{N}}{N-1}} & =
\end{aligned}
$$$$
\mathrm{SD}=
$$

(Gay,

$$
\text { 2006:320) }
$$

Where :

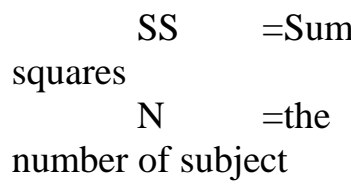

SD

=standar deviation

3. Finding out the significant difference between the pre-test and post-test by calculating the value of the t-test using this faormula:

$$
\mathrm{t}=\frac{D}{\sqrt{\frac{\sum D^{2}-\frac{\left(\sum D\right)^{2}}{N}}{N(N-1)}}}
$$


(Gay, 2006:334)

where:

$$
\begin{array}{ll}
\mathrm{t} & =\text { test of significance } \\
\mathrm{D} & =\text { mean difference } \\
\Sigma \mathrm{D}^{2} & =\text { the sum of }
\end{array}
$$

difference

$$
\left(\sum D\right)=\text { the square of the }
$$

sum of the difference

$$
\mathrm{N}=\text { total sample }
$$

\section{FINDINGS}

The findings consist of data analysis of the instruments that is pre-test and post-test scores. In pre-test, Data were collected from 20 participants which consist of one group. The data was determined in table 1 (see appendix).

Based on the pre-test score, there were not any students classified as very good. There were 3 students classified as good. There were 7 students classified as fair. There were 7 students classified as poor and three students of the classified as very poor, the result of SPSS 23 (appendix on table 2)

After that, the students' post-test score from the participant after treatment of skimming starategy technique. On table 3 (see appendix), the result of the data analysis indicates that 3 students got very good score, 14 students got good score, 2 students got fair score, 1 student got poor score and none of students got very poor score, the result of the of SPSS 23 (appendix on table 3).

To seen the defference of result pretest and post-test is post test score the higher than the pre-test. So, the score mean of posttest is 73.50 and the score mean of pre-test is 39.38 than the score of standart devation pretest is 16.79 and the score of standart devation post-test is 11.821 . It means that there is the a defference of mean score between pre-test and post test. It can be concluded that studentrs reading comprehension has improved after the students taught by skimming strategy.

the calculation of the students mean score t-test from post test and pre-test is $39.38-73.50=34.12$ it proves that there is a significant improvement. It is found the $\mathrm{t}$ value is 13.68 is higher than $t$-table value, in which t-value are 13,68 and t-table 2.039 level significance. The significance value that is 0.000 is lower than 0.05 it means that there is a defference of mean score between pre-test and post-test it can be concluded that students reading comprehension has improved after the students taught by skimming strategy and $\mathrm{df}($ deference of freedom $)$ is $(\mathrm{n}-1)=(20-1)=19$ students

This findings shows that the alternative hypothesis is accepted. So, the hypothesis is really true in this research. It indicates that the students improved in reading comprehension taught by using Skimming technique is higher than those taught by using conventional reading technique.

\section{DISCUSSION}

After conducting the research, the researcher arrived at some findings concerning the use of skimming technique and reading text as reading material on the treatments. From the results of the data analysis, it is found that the total score of students' pre-test score increases from 788up to 1470 in the post-test. The difference of students' score after applying the treatments is 865 points. The mean score in the pre-test is increases to 39.38 in the post-test. Hence, there is an improvement of the students' score about 73.50. The calculation above indicates that there is a significant improvement of students' reading comprehension of reading text after being taught through skimming technique at University of Timor.

Based on the researcher's investigation, before the students were introduced to apply the proper skimming technique, they used to waste their time to understand certain texts in the reading comprehension test. The researcher encouraged the students to apply the skimming technique as a breakthrough, since one of the most effective methods to cope with that problem was by getting a general overview of the text before beginning to read it in detail. Skimming is a technique that helps students to get a sense of its overall logical progression and make decisions about where to place the readers' focus when they have a limited time in reading (Freedman, 2012). With skimming, the readers read only what is important to their purpose. Skimming helps the readers to locate the information and general ideas of the text quickly while making sure they use their time wisely. Based on the result of data analysis, it was proven that skimming helped the students to realize the purpose of their reading activity. 
Then the computation of the mean score of pre-test and post-test proves there that there is a significant improvement from pre-test and post-test. The improvement is 34.12 in whice $\mathrm{t}$-observed value is higher than $\mathrm{t}$-table value at 2.093 level of significance see table 6 it means that the use of skimming strategy to improve students reading comprehension is able to improve the students' achievement and their ability to understand the reading materials. Therefore, the hyphotesis H1 which mentions that there is a significant of skimming strategy to improve the students' reading comprehension is accepted.

Based on the statistical result of the pretest and posttest, it was concluded that most of the students answered the items of finding main idea correctly. One of the main objectives of skimming is to identify the main idea in the text. Skimming which means to read quickly and aimed to look for main ideas in a text makes the readers more efficient at learning material and completing research. By applying skimming properly, the readers could get the essence from reading material without reading all the words. When they could apply skimming technique appropriately, they would be able to decide whether the reading material is useful and need to be read carefully.

\section{CONCLUSION AND SUGGESTION}

The result of analysis suggests an important basis of implementing Skimming technique in enhancing the students reading comprehension. The overall discussion confirms a positive improvement of students' reading comprehension ability after being taught through of Skimming strategy. Before the research, the students ability in comprehending such texts was found to be extremely very low. Therefore, the researcher implemented a different technique, that is skimming technique to overcome the root of the problem so that the students' reading comprehension can be improved.

Most importantly, There is a significant difference on students' reading comprehension in skimming text before and after being taught through skimming technique. It could be identified from the gain of the score and the computation of t-test. The test result shows that the mean score of posttest is higher than pre-test

The aspect of reading comprehension in reading text that is most improved after being taught through skimming technique is identifying main idea. In the pre-test, total score of finding main idea items is 788 , while on the post-test, the score increased to 1.470 . So, the score mean of pre-test is 39.38 up to 73.50 of post-test.

\section{SUGGESTIONS}

The researcher puts forward some suggestions concerning several things that further research should implement. The first suggestion is that further researchers should try to analyze the use of skimming technique to improve students' reading comprehension in other text genres since this research focuses only on the use of skimming technique to improve students' reading comprehension in reading text. Skimming is a good technique when a reader wants to know if a text covers the information he/she needs, especially if the material is non-fiction. Then, further researchers should also conduct similar research at different levels of students, since the technique is appropriate for any level of students. Finally further researchers should conduct similar research in a smaller group of data collecting subject, since it was difficult to monitor the every single subject if the number of students is too large. This research involved the second semester consisting 20 students in treating and collecting the data, so that the researcher was unable to make sure whether every student applied the skimming technique correctly or not.

\section{ACKNOWLEDGMENTS}

Praise to be to the Almighty Lord, intended for the blessings, health, and also inspirations provided to the writer for the completion of this journal. The writer also express her thanks and gratitude to her supervisors, Prof. Dr. Noer Jihad Saleh, M.A and Dr. Sudarmin H.Harun, M.Hum as the coauthors of this study for their valuable help, guidance, ideas, patience, correction, and suggestions, to the Head of English Language Study Program, Dr. Harlina Sahib, M.Hum for his support, her parents and friends for their prayers and support to publish this article. 


\section{BIBLIOGRAPHY}

Alvermann, D.E., \& Moore, D. 1991. Secondary school reading. In R. Barr,M.L. Kamil, P. Mosenthal, \& P.D. Pearson (Eds.), Handbook of Reading Research, vol. 2. New York: Longman.

Brown, H.D. 2004. Language Assessment Principles and Classroom Practices. New York: Pearson Education Ltd.

Caldwell, J. S. 2008. Comprehensin Achievent: A Classroomm Guide. United States of America: Guilford Press.

Gay. L. R., Mills, Geoffrey E., \& Airasian, Peter. 2006. Educational Research: Compotencies for Analysis and Applications. New Jersey: Pearson Education, Inc.

Rahim, Suharty. (2016). The Use of Cognitive Strategies to Improve the Students' Reading Comprehension (SMA Putri Yatama Mandiri Boarding School). Unpublished Thesis. Makassar: Hasanuddin University.

Snow, Catherine E. (2002). Reading for understanding : Toward an $R \& D$ Program in Reading Comprehension. RAND Education. 